\title{
Revisiting the Early Modern Philosophical Canon
}

ABSTRACT: I reflect critically on the early modern philosophical canon in light of the entrenchment and homogeneity of the lineup of seven core figures: Descartes, Spinoza, Leibniz, Locke, Berkeley, Hume, and Kant. After distinguishing three elements of a philosophical canon-a causal story, a set of core philosophical questions, and a set of distinctively philosophical works-I argue that recent efforts contextualizing the history of philosophy within the history of science subtly shift the central philosophical questions and allow for a greater range of figures to be philosophically central. However, the history of science is but one context in which to situate philosophical works. Looking at the historical context of seventeenth-century philosophy of mind, one that weaves together questions of consciousness, rationality, and education, does more than shift the central questions-it brings new ones to light. It also shows that a range of genres can be properly philosophical and seamlessly diversifies the central philosophers of the period.

KEYWORDS: early modern philosophy, women philosophers, philosophical canon, philosophy of mind, education

\section{Introduction}

Philosophers in North America since the early twentieth century have considered the central philosophical figures in the early modern period to be the seven of Descartes, Spinoza, Leibniz, Locke, Berkeley, Hume and, of course, Kant. It was then that, Bruce Kuklick (I984) suggests, William James and Josiah Royce settled on who were the people worth reading, the greatest philosophers of the period.

The writing of this paper was supported by a Partnership Development Grant from the Social Sciences and Humanities Research Council of Canada. I have benefited greatly from discussions with my collaborators in the New Narratives in the History of Philosophy project and in particular with Marguerite Deslauriers, Karen Detlefsen, Sarah Hutton, and Christia Mercer as well as from discussions with Jacqueline Broad, Ruth Hagengruber, Marcy Lascano, Michael Rosenthal, and Amy Schmitter (as well as others I am no doubt forgetting). We all have benefited from reading and discussing related matters with Eileen O'Neill. I have also benefited from comments of two anonymous reviewers as well as discussions at presentations of earlier versions of various parts of this paper at a meeting of the Modern Philosophy Society at the Pacific Division meetings of the American Philosophical Association, the University of Washington Workshop on Fictions in Early Modern Philosophy, the Women in the History of Philosophy Conference at Helsinki Collegium for Advanced Studies, the History of Philosophy of Education workshop at the University of Pennsylvania, the Life and Death in Early Modern Philosophy conference at Birkbeck College, and at the Conference of International Society of Women Philosophers, Melbourne, Australia. 
More than one hundred years later, it might be time to revisit both the storyline and the very idea of a 'great philosopher'.

Arguably, efforts over the past several decades to explore less canonical figures, beginning with the work of Popkin ([I979] 2004) and Watson (I987) and gaining traction with more recent efforts to turn attention to Malebranche (Nadler I992; Schmaltz I996, 2002), Gassendi (Lolordo 2007; Fisher 2005), Newton (Downing 20I4; Janiak 2007), or Reid (Copenhaver 2007, 20I0, 20II; Lehrer I989; Van Cleve 2002, 2007) imply a recognition of a need to refresh the discussion. Nonetheless, there remains a gap between this increased scholarly interest and pedagogical interest. Not many people teach these noncanonical figures in their undergraduate classes. If these figures do get grip, both scholarly and pedagogical, it is because they fit easily into the narrative that drives the canonization of the seven central figures. So, the early modern canon as it stands effectively limits, if not the figures we take as important, then the storylines we take to define the history of philosophy.

There has been another trend over the past several decades. Led by Daniel Garber, historians of the philosophy of the early modern period have aimed to contextualize the philosophy of the period, situating its metaphysics, in particular the metaphysics of body and the nature of space, with respect to the history of science, thereby shifting the storyline subtly. Quite recently that contextualist program has been extended to include the epistemology at work in the experimental science of the period as well as its metaphysics (see Anstey 2000 and 20II). Here too the focus has been scholarly, and if this new contextualist storyline is incorporated into the classroom, it tends to happen by preserving the canonical seven figures while focusing on the metaphysics of body and causation. While the central questions are refocused, the central figures remain the same, even while other figures, such as Gassendi, Boyle, and Newton, are also discussed.

The entrenched stability of the figures in the canon highlights another aspect: its homogeneity (see the 2015 issue of The Monist; of particular interest with respect to my discussion here are Hagengruber [20I 5] and Waithe [20I 5]). In the early modern period there were many women actively engaged in philosophy, and yet most researchers and instructors focused on the early modern period do not read any women thinkers of the period. The momentum here, however, is rapidly changing. No doubt there were also Africans, Arabs, Jews, and Indians in Europe engaged in philosophy, but even fewer of us have been working to rediscover and engage with the work of these figures. (Justin Smith has worked on Anton Wilhelm Amo, and recently Nathaniel Coleman [2015] has discussed African-European philosophers of the period in an interview published online. In addition, Jonardon Ganeri has surveyed Indian philosophical thought of the early modern period, and he suggests, using the example of François Bernier's sojourn in India, that there was significant cross-fertilization of ideas between Europe and India (after Bernier returned to France, he edited the Abregé of the works of Gassendi); see Ganeri [20II]).

Whether or not one shares the sense that the history of early modern philosophy needs to be revisited or is concerned about the homogeneity of the philosophical canon, reflecting critically on our focus on a set of figures and a set storyline 
framed by core questions can allow us to understand better how canons work in our discipline. I begin by considering the function and structure of any philosophical canon so as to be in a better position to evaluate the early modern philosophical canon as it stands and to consider what ought to constitute a philosophical canon. My aim is not to advocate directly for introducing new figures into the canon or removing any one particular figure from it. Rather, I aim to show how our canon might be different. To this end, I provide a case study that focuses on different core questions to develop a storyline. Early modern philosophical accounts of mind were just as distinctive as accounts of body. And just like accounts of body, accounts of mind are offered and picked up in a particular context. Central to that context are philosophical writings about education. By reframing the questions about the mind we take as central, we can not only change up the narrative of the history of philosophy, but also introduce a more diverse and heterogeneous set of figures and works into our philosophical histories. A philosophical canon ought to be driven by central questions, and we do well to look to the history of philosophy to rediscover lines of inquiry that have fallen out of fashion but nonetheless are currently relevant.

I begin my discussion of the philosophical canon by attending to the internal justification of who gets included. By considering the early modern canon as it stands, we can see three central and intertwined elements of this internal justification: the canon depicts a causal account of the intellectual historical development of philosophy around answers to a set of philosophical questions that are centrally constitutive of the discipline presented in set of important distinctively philosophical works. There need be no appeal to philosophical greatness in marking out canonical figures - they need only mark important points in efforts to address central philosophical questions. Kuklick (I984) does take the canon to mark out philosophical greatness, and I do think that many philosophers simply assume the greatness of the canonical figures to justify their status as canonical. But since what counts as philosophically great is elusive and, indeed, admits of cultural variation (the French canon is different from the German canon and both are different from the North American canon), I am inclined to discount this justification, especially since it seems to me that marking a philosopher as great presupposes each of the three criteria I do consider.

In section I, I illustrate how this tripartite account of a canon applies to the traditional early modern canon. In section 2, I show how efforts to contextualize early modern philosophy within the history of science have shifted the central questions subtly, even while preserving a large part of the causal line of intellectual influence as well as an assumption about the genre of a distinctively philosophical work. The case study focused on the intellectual historical context of discussions of the nature of mind, and in particular early modern philosophical discussions of education, which I will consider in section 3, traces a different causal story. In doing so it opens up a new set of philosophical questions-about the interrelation of consciousness, ownership of thought, rationality, education, and habit-as central to the discipline and challenges what defines a work as properly philosophical. Through tracing a new narrative, a set of women (as well as men thinking about women) is introduced as key figures in the philosophical discussion. In these 
ways, the case study provides a demonstration of how to challenge the internal justification of the canon.

In critically revisiting the philosophical canon, it is important to recognize that the canon functions within the discipline in a particular way and that internal to the canon itself are structural features that further justify and stabilize it. First, reading canonical figures in the history of philosophy plays a central role in teaching students what philosophy is: what methods we use, what topics or questions philosophy addresses, and how our philosophical past brings us into the philosophical present. The canon thus has a pedagogical function. Second, as Richard Rorty (I984) noted, the canon also serves to justify contemporary philosophical interests. Contemporary philosophers often want to situate their current work within a long-standing tradition in order to position their contemporary discussions as making progress from earlier engagements with the same or similar questions; the canon thus serves as a Geistesgeschichte. ${ }^{\mathrm{I}}$ While these are conservative pressures, they can also be leveraged. I conclude by considering whether a destabilized canon can continue to function pedagogically and how it can help support contemporary philosophical concerns. It is an important function of work in the history of philosophy to open new lines of contemporary inquiry and equally, to provide the resources to support those investigations so that these new lines of inquiry are easily introduced into teaching.

\section{The Canonical Story of Early Modern Philosophy}

To illustrate these justificatory strategies, consider the traditional early modern canon. It purports to depict a causal chain of intellectual events that begins with Descartes, a figure depicted as essentially self-caused. ${ }^{2}$ His philosophically innovative dualist metaphysics impacts Spinoza and Leibniz, each of whom read Descartes, and Leibniz read Spinoza. Each of them develops his own philosophical system in response to perceived strengths and weaknesses in Descartes's account, preserving the epistemological insight that knowledge is grounded in the nature of the human mind or reason while resisting Descartes's view that there are two existentially independent finite substances (independent save for their dependence on God): mind and body. Spinoza takes issue with the consistency of Descartes's

I Note that Rorty assumes that the history of philosophy does have value and is concerned to articulate just wherein that value lies. One might assume that contemporary philosophical discussion is interesting just because people are currently interested in what they are doing. I endorse Rorty's assumption and am not interested here in trying to justify the study of the history of philosophy to those who are uninterested in it. I will just make two observations. First, even contemporary philosophy becomes the history of philosophy sometime: the new subfield of the history of early analytic philosophy bears this out. The shape of my discussion here may well help in the development of that narrative. Second, it also seems that many threads in contemporary philosophical discussion could be enriched by looking to historical antecedents.

2 This aspect of the standard story has long been challenged, at least since Etienne Gilson's Index ScolasticoCartesien ([I9I3] I960). Recent scholarship aimed at demonstrating the debt Descartes owes to his predecessors includes work by Robert Adams, Roger Ariew, John Carriero, Dennis Des Chene, Helen Hattab, Paul Hoffman, Stephen Menn, and Marleen Rozemond. 
ontology and argues that there is only one substance, infinite substance, which has infinitely many infinite attributes, of which thinking and extension are two-the two we human beings are capable of understanding. Leibniz, in turn, responds to both Descartes and Spinoza, aiming to address the intractable problem of the interaction of really distinct substances while resisting monist metaphysics and preserving individuals. In his ultimate view, what exists are monads, the only entities with a complete individual concept, each of which expresses the whole universe, though not all of it clearly. The particular entities we encounter are simply aggregates of monads that stand in preestablished harmonic relations with one another.

Locke too is impacted by Descartes though Locke develops an alternative to the Cartesian epistemological system, rejecting innatism about reason and taking knowledge as grounded in experience and remaining largely agnostic about metaphysics, with the possible exception of a fundamental human power to act, or liberty, and the nature and existence of God. For Locke, pure substance in general is 'something I know not what' that serves as that substrate in which qualities inhere, rather than a self-subsisting entity. Particular substances are simply whatever is picked out by the names we assign to clusters of qualities that come together. However, just as Descartes's dualism has its issues, so too does Locke's commitment to the primacy of sense perception. Berkeley and Hume read Locke carefully (and Hume read Berkeley) and adopt Locke's empiricist commitments, but they develop their own philosophies to avoid problems in Locke while preserving empiricism. They might share Locke's nominalism about particular substances, but they each point out key assumptions that escape Locke's empiricist methodology. Berkeley demonstrates that there is no basis in experience for drawing distinctions between the properties we take to be essential to bodies and those we take as dependent on our perception. Hume takes on causation, applying empiricist principles to the articulation of that concept. The intellectual causal chain of the canonical story leads inexorably to Kant as its culmination. Much is made of Kant's claim that Hume woke him from his dogmatic slumbers and so of the causal link between Hume and Kant, but it is also the case that Kant is taken to synthesize the insights of those writing in both the Cartesian and the Lockean traditions in such a way that he avoids the pitfalls of each tradition.

The second internal justificatory strategy is deployed in the construction of this well-worn story. A small set of core philosophical questions structures the storyline: the epistemological question of the basis for claims to knowledge and the metaphysical questions of what sorts of things exist and how they causally interact. Noncanonical figures have been worked into the narrative in virtue of their addressing these questions. Malebranche is introduced as a leading figure of Cartesianism who fleshes out how the nature of mind grounds knowledge by appealing to our perception of ideas in the mind of God and who develops a theory of occasional causation to address issues about causal interaction of distinct substances (See Malebranche ([I674] I 997)). And occasional causation prefigures Hume's account of causation. Gassendi offers us an earlier version of the empiricism championed by Locke, though, as the author of the Fifth Objections to Descartes's Meditations, Gassendi is not so much causally influenced by Descartes as in collision 
with him. Reid is understood as developing his account of the powers of man in direct response to Hume. It should be clear that these questions-about the nature of mind and how that nature affords the possibility of knowledge, about what exists, and about the nature of causation-are still central in contemporary philosophy. It should be equally clear that questions concerning moral, social, and political philosophy are pushed into the background. They are typically addressed in a history of ethics course, completely separated from the rest of the discussion of the philosophical period.

Just addressing a central philosophical question, however, is insufficient for a philosopher to be incorporated into the canon. Canons are essentially conservative, and canonical figures have a distinctive authority. At least part of the authority derives from their having written what is deemed a major philosophical work, as if that is a genre unto itself: the Meditations, Ethics, Monadology, Essay Concerning Human Understanding (hereinafter ECHU), Principles of Knowledge, Treatise on Human Nature, and of course, Critique of Pure Reason-they are all supposed to be of a piece. To introduce a new figure into the canon, we appeal to that person having written a philosophical treatise, a work of a particular genre, for that legitimizes the person as a philosopher. ${ }^{3}$ This rationale for legitimizing new canonical figures then quickly becomes a criterion for marking out any proper philosopher: a legitimate philosopher must have written a proper philosophical work, where a proper philosophical work is taken to be a work of a particular genre, the genre of the other great works.

\section{Contextualism and a Subtle Shift in the Story}

Recent efforts by historians of early modern philosophy have aimed to contextualize the philosophical positions within the history of science. As the result of this contextualization, there has been a subtle shift in the questions driving the philosophical storyline. Rather than focus on epistemology, and in particular answers to skepticism or the metaphysics of substance, scholars are delving more deeply into metaphysical questions about the nature of body.

The narrative arc starts from Descartes's definition of body as extended substance and examines debates about the nature of extension or space, such as whether space is a plenum or can support a vacuum, what body is, and how bodies are individuated within space, and in particular whether there are atoms. The traditional question of the nature of causation is refocused to consider the nature of the interaction between bodies, including whether bodies have causal efficacy, and the basis of the laws of nature governing those interactions.

While the central questions have shifted slightly, the central characters of the storyline remain largely the same. Descartes and Leibniz figure prominently;

3 There are, of course, complications. Gassendi's posthumous Syntagma philosophiae Epicuri (I649) is a comprehensive six-volume treatise covering logic, physics and ethics, that is, the whole of philosophy. It might well be claimed that the sheer size of his masterwork while granting him legitimacy also undercuts any efforts to canonize him: there is simply too much there to fit him neatly into the storyline. 
Locke and Kant too play a lead roles though why they are important has shifted. Locke's appropriation of atomism and mechanism rather than his theory of ideas is what pushes him to center stage. And while Kant's epistemology continues to be important, his metaphysics of the foundations of science has gained prominence. But there is also a shift. Until quite recently, Spinoza faded into the background (Peterman [2015] helps to reintroduce Spinoza into the shifted storyline). Berkeley has all but disappeared from view, and while Hume still figures in the story, the focus is simply on his account of causation. But new characters in the story begin to emerge. To extend the story of the account of extension, or space, that begins with Descartes and then is critiqued by Leibniz, we need to recognize the dispute between Leibniz and Newton, and Newton's representative Samuel Clarke, and how this dispute provides the context through which to understand Kant. Equally, to understand better Locke's atomism and mechanism, we look to Gassendi's earlier atomism, to Hobbes's mechanism as well as to the work of Robert Boyle. Shifting the questions, even subtly, provides a space through which new central characters can be introduced and with them new articulations of the causal relationships between philosophers that drive the storyline forward.

It is worth highlighting just how opening this space by shifting the central questions is already helping to address the homogeneity of the canon. For in focusing on questions about the nature of extended substance, it is possible to introduce seamlessly women thinkers whose works directly address these questions. Recently, scholarly attention has been directed to Margaret Cavendish and Émilie du Châtelet. Cavendish revives Stoic physics in her doctrine of complete blending, which understands bodies to be a mixture of inanimate, animate, and rational matter, the different proportions of which serve both to differentiate kinds of things and, along with shape and common motion, to explain the properties of those kinds and their interaction through a kind of patterning or mirroring. Her Observations on the Experimental Philosophy ([1666] 200I), Philosophical Letters (I664), and Grounds of Natural Philosophy (I668) serve to articulate the physics, including an account of causal interaction, and situate her position with respect to Descartes, Hobbes, and van Helmont (a figure who has yet to make it into canonical discussions). Du Châtelet translated Newton's Principia into French, and her introduction to that translation is a substantive philosophical commentary on the work. Her views are worked out in more detail in her Institutions de physique ([I740] 2009), in which she puts forward an account of scientific reasoning as well as accounts of space, time, and the laws of nature. Her extensive discussion of gravity in that work includes an account of natural forces. Insofar as these women are directly engaged with a set of questions concerning metaphysics of natural science, which a contextualized history of philosophy demonstrates as central to philosophy in early modern Europe, they are easily integrated into the storyline. Indeed, to neglect them is to do a disservice to our understanding of the history of philosophy.

There are two other points to make regarding this contextualist approach to the history of philosophy. First, the shift in central questions prompted by this contextualism parallels developments in contemporary philosophy and, especially, in the philosophy of science. For much contemporary philosophy of science has 
moved away from general concerns about scientific explanations and toward philosophies of the special sciences, including philosophy of physics. Contemporary debates about the nature of space find their antecedents in early modern debates, as do current discussions of laws of nature and of causation. The reconfigured canon thus continues to play its justificatory role with regard to contemporary philosophical interests.

Second, the contextualist approach still appears to privilege a particular kind of text as philosophical. Figures who gain prominence in the rewritten story, Gassendi, Boyle, Newton, and equally, Cavendish and Du Châtelet, all wrote treatises. Correspondence engaging with these figures, like that of Clarke with Leibniz, is also important, but serves to buttress the central storyline.

\section{Another Context: Human Freedom, Education, and Autonomy}

Situating early modern philosophy within the context of the development of modern natural science subtly shifts the central questions within the canon, opens it up, and allows for a cast of central characters that is more heterogeneous and reflects the diversity of active intellectuals of the period. However, while the scientific revolution is certainly an important part of the context of early modern philosophy, it is not the only significant intellectual development of the period. Schneewind's The Invention of Autonomy (I998), for instance, situates the development of the Kantian concept of autonomy, focused on the shifting roles of divine and human will and their relationship, within the context of the Protestant Reformation, the wars of religion, and the development of Republicanism as a political theory. The story helps to structure contemporary philosophical discussions of autonomy, moral agency, and responsibility and so plays the justificatory role that we take a canon to play. ${ }^{4}$

These two stories, however, need not be the only ones we tell. Indeed, if we focus only on them, we will find that a very important philosophical development of the early modern period, and equally a central concern of contemporary philosophy, gets comparatively short shrift in contextualist philosophical histories: the mind. In what follows, I sketch another storyline, one that starts from a consideration of the nature of the human mind. One way to tell this story is to start from a question central to contemporary philosophy and find its roots in the canonical figures of the past. Contemporary concerns with consciousness and its relation to perception find their roots in the early modern period. For Descartes, and arguably for Locke, consciousness is a mark of the mental, though Spinoza and Leibniz take issue with this claim, developing views of how we come to be conscious of our ideas and

4 Again we see that this contextualism opens up the array of figures to be considered. One need only review the table of contents of Schneewind's work to see that this is no canon of seven figures. There is nonetheless a familiar homogeneity to the cast of characters, and this is somewhat surprising given how many women thinkers of the period were invested in arguments defending human beings as freely willing beings, and hence as capable of rationality and self-determination. 
thereby represent the world to ourselves. This strategy updates the canon with a new central question, ensuring that it stays relevant to contemporary philosophical discussion. However, it leaves the same canonical figures in place.

If we consider how a view of the mind as intrinsically self-aware, or at least capable of self-awareness, gets taken up in the historical context, we will find ourselves presented with a set of possibilities both for reframing questions and for including a new heterogeneous set of figures. In the seventeenth century, accounts of mind were intertwined with debates about the rationality of women, with accounts of learning, and with models of education and a movement to educate women. The discussions highlight the significance of owning one's own thoughtswhat consciousness affords-for rationality, the need for education to cultivate that ownership, and the tension between that end of education and the way the institution of education itself inculcates customs and habits in students, that is, the tension between our autonomy and the customs and habits required to become fully free autonomous agents. The storyline I provide here is only a sketch, with many gaps to be filled in, but my aim is to provide a case study showing how by attending to historical context we can do more than simply reframe well-established questions; we can recognize philosophical questions that contemporary philosophy is neglecting and so can open up new lines of contemporary inquiry.

It is a commonplace that for Descartes, consciousness is the mark of the mental, and as the cogito demonstrates, consciousness consists in a particular selfawareness. When we are thinking, we cannot but be aware that we are, even if we mischaracterize what we are thinking about. Less acknowledged is that the awareness proper to thinking has implications for our own freedom and for rationality. For Descartes, freedom consists in the power to do otherwise, but to know our own freedom, and so to be fully free, it is insufficient to describe features of the will. That is, we can describe features of the will without fully understanding that we ourselves have a free will. Rather, our knowledge of our own freedom-that which truly belongs to us and on the basis of which we can be evaluated morallyderives from our experience, that is, from our awareness of exercising our will. But there is a gap between exercising our will and experiencing that exercise: we need to become aware of just what it is we are doing. Descartes's exchange with Gassendi in the Fifth Objections and Replies brings this point to the fore. In his Objections, Gassendi raises questions about how Descartes conceives of the freedom of will and in particular about his conception of indifference. Descartes replies that 'I am not prepared to set about proving [these propositions] here. These are the sorts of things that each of us ought to know by experience in his own case, rather than by having to be convinced of them by rational argument' $(7: 377, \mathrm{I}: 259)$. He goes on to remark to Gassendi that he does think Gassendi is free but is simply failing to notice his own demonstration of that freedom, evidenced by the act of denying. If Gassendi were simply to notice just what he was doing, Descartes implies, Gassendi would learn the nature of his own freedom. It is only with that awareness that we properly understand that we are free (I develop this interpretation more fully in Shapiro [2008 and I999]; see also Boehm [20I4]).

But if we can exercise our will without our being aware that we are free, how is it that we do become aware of our freedom? The Meditations suggests that only 
we, on our own, can become aware of our freedom. The meditator is presented as an autodidact. He turns away from his previous beliefs, the habits of thought that have been inculcated in him, and is left with simple reflection-his own nature as a thinking thing. Just through self-reflection he discovers his freedom. And that discovery in turn leads to another-the method for avoiding error-the standard of rationality.

The Discourse, however, suggests something a little different. There, through the extended description in Part I of the education he received, Descartes suggests that there is a real sense in which he never would have discovered his method of rightly conducting reason-that is, he never would have taught himself what he did-without his having been suitably acculturated, having read a set of texts playing an important role in forming the community of which he is a part, being given the tools to help address the problems his community faces, and learning the rules that govern that community through that education.

What is not clear is how discovery of the proper method of reasoning derives from the prior customs and habits taught to him by others. Certainly, acculturation and education give us the language to express our thoughts, and to reflect on them, considering whether they might be false and choosing to believe or disbelieve them. Education also exposes us to an array of different events and experiences, attitudes toward the commonplace and the extraordinary, as well as problems that we have never imagined or encountered and the means of addressing them. This expansion of our experience beyond the local context might allow us to imagine that things might well be otherwise and that we might act otherwise. That is, education can help us to recognize our own freedom. The study of logic and mathematics can help us in identifying and resolving problems, and through these studies we learn the norms of rationality and so develop the ability to identify faulty syllogisms and miscalculations. We thus do depend on our education for all the tools we use in recognizing that we are thinking and free and in using that capacity for thought well.

Descartes's account of mind certainly involves consciousness, but it also involves how that consciousness is connected to our own exercise and experience of our freedom and rationality. It raises questions not simply about the character of that awareness but also of how we come to recognize for ourselves that we are aware and, equally, that we are free. That is, Descartes's account of mind raises questions of how we know our mind and own our thoughts. And it also raises the question of the relation of education, its associated development of habits and social acculturation to and our self-knowledge.

Framing the central philosophical questions in this way resonates with a set of very lively debates in the period about the rationality of women. Starting in the late thirteenth century, one can trace the so-called querelle des femmes (debate on women) through a series of texts alternating arguments that women are inferior to men, less rational, more vicious with those defending women as superior and closer to wisdom and virtue. In the seventeenth century, that debate seems to reach a turning point: for the first time there are arguments for the equality of men and women. These arguments turn on claims about education.

Perhaps the first argument for equality of men and women comes in Marie De Gournay's essay On the Equality of Men and Women (1622, for translations 
see Gournay [2002] and Clarke [2013]) in which she adopts a skeptical method to arrive at that conclusion. Interestingly, in that essay, she offers an argument about the important role differences in education play in explaining the differences between Italian women (cloistered and inexperienced) and English and French women (active in the world) and similarly their male counterparts (Italian men are well-educated, while French and English men are not), showing that differences in apparent rationality are not natural but the result of education. She suggests that it is through education that women become active and independent participants in the world.

Anna Maria van Schurman's Dissertatio de Ingenii Muliebris ad Doctrinam (I638, published one year after Descartes's Discourse; modern translations can be found in van Schurman [1998] and Clarke [2013]) takes up this idea, though she sets limits on the appropriate degree of public engagement women should have. The series of syllogisms she offers demonstrate that it is fitting for a Christian woman to be educated in two ways. First, on their face, the syllogisms provide a set of inferences to that conclusion. But equally, insofar as the work's author is a woman, it enacts what it aims to prove, providing evidence of a woman's natural ability to reason. Moreover, insofar as the conclusion is at odds with the dominant Aristotelian tradition, which takes women to be defective human beings, the syllogisms show just how their author has taken ownership of Aristotelian rules of reasoning. There is a resonance here with Descartes's account in the Discourse of his appropriation of his own education to arrive at his own view of the nature of thinking. Van Schurman's work, thus, exhibits a tension similar to that found in Descartes's works. Human beings have a natural capacity to reason, and reasoning, or thinking, involves our ownership of our thoughts. There is nonetheless a place for an education that teaches us rules for conducting reason.

It is not obvious how education is consistent with our developing into rational beings, where rationality involves essentially owning our thoughts. Education, after all, is structured so that those in authority instill habits in us. John Locke, in his Some Thoughts Concerning Education ([I693] 2000), certainly sees the function of education as instilling habits, in particular those that promote virtue. The work begins with a set of exercises to cultivate bodily habits that will 'endure hardships' and serve a child well as he grows into an adult, travels to different regions and even countries, and, most significantly, develops his understanding. It also includes the development of habits of mind that serve a similar purpose, but here the hardships that the mind must learn to endure are its own desires. As Locke sees things, we are driven by uneasiness in feeling the absence of those things that give us pleasure: we desire to remove that uneasiness, and so regain our feelings of satisfaction and joy (ECHU 2.20.6). But these desires need not themselves conform to reason, and we need to learn early to deny ourselves the satisfaction of our errant desires. The role of education is to inculcate in us early the habits of this denial.

It can seem that Locke's view that education consists in instilling proper habits runs counter to the role I have been suggesting it plays in Descartes's Discourse, in Gournay's essay, and in van Schurman's Dissertatio. For Locke, there seems little room for owning our thoughts, insofar as schooling consists in being inculcated 
with manners, customs, and habits that are fitting to the pupil's position. Yet, as with Descartes, for Locke, volition, the mind's exercise of dominion over itself, is central to human nature. We can perhaps see his prescription for education as a precursor to the exercise of volition. A good education teaches us to deny ourselves the satisfaction of our desires, motivations that nature has given us. Acquisition of these habits of self-denial is hardly voluntary as they do not involve knowingly redirecting desires. Nonetheless, the instilling of these habits gives a child practice in denying his desires, so that, when he does actively will to do one thing rather than another, he can exercise his will without difficulty. Education, as Locke details it, thus provides not only the tools we need to exercise our will, but also a kind of practice in denying what has been given to us. Insofar as we have come into the habits of refusing the satisfaction of our desires and redirecting them, we are preparing to choose knowingly to do or not to do something, whether that be believing or some other action.

Exercising our will-exercising dominion over ourselves-involves at a certain point denying that to which we have become habituated. How does that happen? Locke himself says little in this regard. Indeed, he makes it seem easy. And maybe since the role of the philosopher inevitably involves raising objections, for us who are so habituated to thinking otherwise, this denial can seem easy. But it is important to recognize that it is often not easy to call into question one's habits, especially if they are deeply entrenched and serve to structure our everyday lives.

We can return to the historical context to see that just this question was raised, once again, with regard to the education of women. In the preface to his $A$ Physical and Moral Discourse concerning the Equality of Both Sexes ([I673] 20I I, translated in Poullain de la Barre [2002] and in Clarke [2013]), a title echoing De Gournay's essay, Poullain notes the points worthy of imitation in the fable Descartes presented his readers in Part I of the Discourse: calling into question traditional education, the pursuit of truth as individuals, examining one's own beliefs, and noting and correcting one's prejudices. ${ }^{5}$ For Poullain, a prejudice is not simply a false belief, though it is also that. 'Prejudice' is a technical term, referring to judgments we make unreflectively, that is, without examination; these judgments are 'entrenched' or solidified, inculcated through habit and custom, and so serve to structure our understanding of the world around us. These prejudices are not simply the inevitable consequence of our imperfect knowledge, but rather are akin to, in contemporary terms, implicit biases. This becomes clear through Poullain's illustration.

Poullain takes the Cartesian method to be invaluable for eradicating these prejudices. To illustrate its value in this regard, he selects one particular opinion that seems to be held universally-and so seems to be necessarily true-and aims to show it to be, in fact, a prejudice and ill-founded. The opinion on which he focuses is the inequality of the sexes: 'Among all the prejudices, no one has found a

5 'The best idea that may occur to those who try to acquire genuine knowledge, if they were educated according to traditional methods, is to doubt if they were taught well and to wish to discover the truth themselves. As they make progress in this search for truth, they cannot avoid noticing that we are full of prejudices, and that it is necessary to get rid of them completely in order to acquire clear and distinct knowledge' (Clarke 20I3: I I9). 
more appropriate one with which to illustrate my thesis than that which commonly accepts about the inequality of the sexes' (Clarke 20I3: I20). The only basis for this belief, Poullain aims to show, is 'custom and superficial experiences', and if women do appear unequal to men it is because of the way that 'women have been dominated and excluded from the sciences and from public life' (Ibid.). Poullain's choice of this particular belief for examination exposes how some of our customary beliefs can be enmeshed in a social and political order that institutes a hierarchy of values that are further affirmed through education. Because of the extent to which such a belief is intertwined through so many of our other beliefs, dislodging it or even leaving it open for revision, proves to be challenging. For people are convinced that 'if some practice is well established, then we think that it must be right' (Clarke 2013: I25). Pointing out that 'is' does not imply 'ought' is of little use. Indeed, the belief is so entrenched, Poullain notes, that it seems as if women themselves 'tolerate their condition'. The challenge is to demonstrate and persuade people of the falsity of this belief.

In this work, Poullain constructs a whole new narrative, offering a causal history of how the social order ended up as it is. That account is meant to provide an alternative explanation of the origin of particular traits that ground claims of inequality and thereby to facilitate our revising our evaluation of them. In his second work on the same theme, On the Education of Women in Guiding the Mind in the Sciences and in Morals (1674, translated in Poullain de la Barre [2002]), Poullain adds to this account. For he recognizes that it makes sense that most of our beliefs are instilled in us by others: we depend on others for our most basic needs from birth and so simply accept their authority with respect to what there is and the value of those things. To overcome this dependency on the epistemic and moral authority of others and to ensure that we do not succumb to prejudice, we need to look inward and find a special kind of confidence, one that recognizes that our ability to justify our beliefs is on equal footing with that of others. That is, we need to recognize that we have authority in settling on our thoughts. With this authority comes a responsibility for ensuring that our thoughts are well-founded, based on good reasons and not simply on common practice. This does not mean that we are to arrive at our beliefs wholly on our own, but rather that we ought to defer to others' judgment only when they have demonstrated expertise through their ability to convey to us clearly their own understanding. That is, we ought to rely on the testimony of others only when they have taught us what they know in such a way that we too can understand it.

It does not seem that Poullain thinks it is particularly difficult to find the confidence in our own authority. It may require being placed in the right circumstances, but for him those circumstances seem relatively easy to come by. Is this in fact the case? The particular context of Poullain's discussion adds force to the question. The work begins with the recognition that women often lack epistemic and political authority and 'tolerate' their condition. Given this condition, it is a particular challenge to convince women that they can listen to their own reason rather than defer to popular opinion.

Mary Astell in her Serious Proposal to the Ladies ([I694 and I697] 2002) addresses this challenge. Indeed, she identifies the kind of education women have 
received, the habits inculcated in them, and the customs to which they have been acculturated as undermining their ability to understand properly their nature as human beings and so to value themselves properly. Her Serious Proposal aims to rectify this situation.

As Astell presents it, women's upbringing has focused their attention on the minute details of their physical appearance-their dress, their carriage, their movements in dancing, their conversation so as to charm-ultimately in the service of securing a husband. In having this focus, Astell is clear, women value themselves incorrectly in two distinct ways. First, women take their bodies to be the locus of their value, and so their minds are put to work on how best to perfect their bodies; second, they value the opinion of the men whose approval they seek. In doing so, they fail to see their minds as the source of their value, but they also cede the standards by which they will be valued to the men they are aiming to attract. That women are misguided in these ways is not something intrinsic to the female condition. A proper education would afford women the confidence in their own judgment and so the ability to resist the force of those 'silly Artifices' and other customs and habits that are foisted upon them.

In the first part of the work (1694), Astell polemicizes about the need for such an education. In the second part, published three years later (I697), she drops her polemical tone and presents the program of her educational system in a straightforward manner. The program bears a striking resemblance to Descartes's method, as it is articulated in the Discourse: properly circumscribe the question, reason only with clear ideas, in order from the simplest to the more complex, through a full enumeration of the question's various aspects, remaining focused and withholding judgment from that which we do not understand. Astell proposes quite simply to give the women she aims to reach practice in reasoning. The hope is that these habits of thought can be applied to other things, in particular to critically evaluating the manners and customs in which women have been raised, an approach suggestive of the role of habits of mind in Lockean education. ${ }^{6}$

It should be clear that this sketched narrative developed by historically contextualizing early modern accounts of mind involves a more heterogeneous set of authors-half of the figures I have discussed are women. It is also clear that the narrative satisfies one of the defining elements of a philosophical canon. We can trace lines of causal influence between the central texts and figures in the story. The skeptical method deployed by Gournay is also deployed by Descartes (they share being influenced by Montaigne). Poullain is clearly adopting Cartesian method to argue further for Gournay's claim about the equality of men and women. Descartes's influence can also be seen in Astell, who indicates she read Descartes's Principles of Philosophy and who would have had access to Cartesianism through her correspondence with the Malbranchean John Norris. ${ }^{7}$ And Astell is clearly situated in a line of arguments for women's education, including those of Gournay and van Schurman.

6 In her recent work Jacqueline Broad (Broad 20 I 5 ) develops a full interpretation of Astell as a virtue theorist. 7 She may have also had access to Descartes's Discourse, which was translated into English in I655. 
It is less clear, however, whether the narrative draws on distinctively philosophical texts. It includes essays, a dissertation or a set of syllogisms, a discourse, a treatise, a dialogue, and a polemic. Surely, the Discourse is philosophical, though it was written in the vernacular for a popular audience. Are the other texts philosophical? Simply the fact that they were written for a popular audience, that they are engaged in matters of public interest, does not disqualify them from being philosophical texts.

Indeed, a little reflection on philosophical classics, if not canonical texts, makes it clear that a philosophical genre has little to do with what counts as a properly philosophical work. The works of Plato are dialogues, after all, and that genre is widely adopted in the early modern period. Consider Malebranche's Dialogues on Metaphysics and Religion ([1688] I997), Berkeley's Three Dialogues Between Hylas and Philonous ([I7Io] 2009), and Hume's Dialogues Concerning Natural Religion ([1779] 2007]. Dialogues are not the only literary genre adapted to philosophical ends. Lucretius's De rerum natura ([56] I975) is an epic poem that conveys Epicurean atomism into the early modern period. Montaigne invents a genre, the essay, as a test of his own thoughts (Montaigne I958). By the time Locke writes his Essay Concerning Human Understanding ([I690] I975), the genre has taken root. Other early modern works play with genre. Mandeville's Fable of the Bees (I7I4) presents a substantive moral and political philosophy in an array of genres: a poem, an essay-like argument, and a set of remarks. Bayle's Dictionary ([1696] I99I) purports to be a series of expository entries about particular figures and views, but it is also a typesetter's nightmare of footnotes and marginal notations in which some of the most substantive philosophical points are made. Spinoza appropriates the genre of geometry to present his Ethics ([1677] I994). Perhaps most significantly, Descartes quite intentionally presents his novel philosophical program in the array of genres evidenced in the Discourse on Method, the Meditations, and the Principles of Philosophy. The idea that there is one distinctive philosophical genre simply does not withstand scrutiny, and so it seems to me that there is no good reason not to take the works central to the storyline I have sketched as philosophical.

This leaves the matter of whether the questions driving this narrative are central to philosophy. There are three distinct points to make here. First, some of the questions driving the narrative-about the relationship of our habits of thinking and our ownership of our thoughts-resonate with recent discussions about selfknowledge, epistemic injustice, and implicit bias in epistemology and philosophy of mind. Attention to historical narratives like the one I have sketched here can serve to legitimize contemporary discussions, situating them in a longer historical context, and attention to historical texts concerned with similar issues can provide a perspective through which to advance the discussion.

Second, it might seem that the questions addressed in the historically contextualized narrative I have presented-questions of the importance of education to realizing our nature as conscious, thinking things, cultivating our owning our thoughts, being independent thinkers and so ultimately independent agents-are applied rather than central. The central questions, one might think, 
revolve around the nature of consciousness and its role in representation. Note, however, that the historical context shows us how a philosophical view about mind is worked out in the early modern period in a way entirely analogous to the way a philosophical view about body is worked out in the development of modern science. The questions in this narrative are no less applied than those relating to the physics of the period. Moreover, this historical narrative brings two strands of contemporary philosophical discussion into contact with one another: that of consciousness and that of autonomy, for consciousness is aligned with ownership of our thoughts, which is in turn required for autonomy. While these contemporary strands have each traced a line to their historical antecedents, they have also neglected those antecedents that help to highlight their points of contact. By considering this new narrative in the history of philosophy we can develop new lines of contemporary inquiry from existing ones.

Finally, questions about the role and form of a good education play a central role in the narrative. Perhaps education is also worth highlighting as a central philosophical question because of the very pressures facing education in our current time. There is a long tradition of canonical philosophers discussing educationfrom Plato to Augustine to Rousseau to Dewey and the works I have mentioned here. We are at a moment where we seem to be asked to justify the noninstrumental value of education, and it would be a good thing to draw out the history of philosophical thinking about education's intrinsic value in our efforts to address the current challenge.

\section{Relation of Scholarship and Pedagogy}

In thinking about the philosophical canon, it is important not to undervalue the role it plays in teaching. The canon provides students at different institutions with a set of common texts through which they can interact meaningfully with one another. It provides similar continuity to students as they move through the curriculum in their home institution. Thus, it might be tempting to suggest that there should be a break between scholarship and pedagogy. Disrupting the canon might be fine for research, but the curriculum should remain intact.

While I respect this impulse, I want to push back against it. First, nothing in what I have argued requires dismissing or failing to take up currently canonical texts. Very few instructors cover all seven figures in a survey course; we all make choices regarding which philosophers to highlight. It is better to make explicit how those choices are made, and simply doing that can open up pedagogical possibilities. Second, disrupting the canon need not entail giving up the figures we were trained in or giving up the precision of articulation that has been the hallmark of the philosophical enterprise since Socrates. Rather, in directing attention to new figures and new texts, we can not only gain insight into the logical space of answers to currently central philosophical questions, but we can also rethink how we frame those questions. Asking questions in new ways enriches how we think about our discipline, our own research, and equally how we share those thoughts 
with students; thus, it can help us reinvigorate the history of philosophy and ensure the continued vigor of the discipline as a whole.

LISA SHAPIRO

SIMON FRASER UNIVERSITY

lshapiro@sfu.ca

\section{References}

Anstey, Peter. (20I I) John Locke and Natural Philosophy. Oxford: Oxford University Press.

Anstey, Peter. (2000) The Philosophy of Robert Boyle. London: Routledge.

Astell, Mary. ([1694 and 1697] 2002) A Serious Proposal to the Ladies. Edited by Patricia Springborg. Peterborough, Ontario: Broadview Press.

Bayle, Pierre. ([1696]I99I) An Historical and Critical Dictionary. Edited by Richard Popkin. Indianapolis, IN: Hackett.

Berkeley, George. ([I7IO] 2009) Principles of Human Knowledge and Three Dialogues. Edited by H. Robinson. Oxford: Oxford University Press.

Boehm, Omri. (2014) 'Freedom and the Cogito'. British Journal for the History of Philosophy, 22, $4,704-24$.

Broad, Jacqueline. (2015) The Philosophy of Mary Astell. Oxford: Oxford University Press.

Carriero, John. (2009) Between Two Worlds: A Reading of Descartes's Meditations. Princeton, NJ: Princeton University Press.

Cavendish, Margaret. ([I666] 200I) Observations upon Experimental Philosophy. Edited by Eileen O’Neill. New York: Cambridge University Press.

Cavendish, Margaret. (I 668) Grounds of Natural Philosophy. London.

Cavendish, Margaret. (I664) Philosophical Letters. London.

Châtelet, Émilie du. (I740) Institutions de physique. Paris: Prault fils.

Châtelet, Émilie du. (2009) Selected Philosophical and Scientific Writings. Edited by Judith P. Zinsser and translated by Isabelle Bour and Judith P. Zinsser. Chicago: University of Chicago Press.

Clarke, Desmond. (2013) The Equality of the Sexes: Three Feminist Texts of the Seventheenth Century. Oxford: Oxford University Press.

Goleman, Nathaniel. (2015) 'Interview with Aaron Salzer, "Wie die Philosophie 'weißgewaschen' wurde". Available at http://science.orf.at/stories/I759195/. English translation published at Gender Race and Philosophy: The Blog; available at http://sgrp.typepad.com/sgrp/201 5/o8/ how-philosophy-was-whitewashed-an-interview-with-dr-nathaniel-adam-tobias-coleman-byaaron-salzer-of-scienceorfat-t.html.

Copenhaver, Rebecca. (2007) 'Reid on Consciousness: HOP, HOT or FOR?' The Philosophical Quarterly, 57, 6I3-34.

Copenhaver, Rebecca. (2010) 'Thomas Reid on Acquired Perception'. Pacific Philosophical Quarterly, 9, 285-310.

Copenhaver, Rebecca. (20I I) 'Reid on the Moral Sense'. Canadian Journal of Philosophy, suppl. Special Issue: New Essays on Reid, 4I, 80-IоI.

Descartes, René. (I984-I99I) The Philosophical Writings of René Descartes. 3 vols. Translated and edited by J. Cottingham, R. Stoothof, D. Murdoch, with A. Kenny in vol. 3. Cambridge, UK: Cambridge University Press.

Descartes, René. (I996) Oeuvres de Descartes. I2 vols. Revised edition, edited by C. Adam and P. Tannery. Paris: J Vrin.

Downing, Lisa. (2014) 'Locke's Metaphysics and Newtonian Metaphysics'. In Zvi Beiner and Eric Schliesser (eds.), Newton and Empiricism. (Oxford: Oxford University Press), 97-I I 8.

Fisher, Saul. (2005) Pierre Gassendi's Philosophy and Science: Atomism for Empiricists. Boston, MA: Brill. 
Ganeri, Jonardon. (201 I) The Lost Age of Reason: Philosophy in Early Modern India, I450-I700. Oxford: Oxford University Press.

Garber, Daniel. (1992) Descartes's Metaphysical Physics. Chicago: University of Chicago Press.

Gassendi, Pierre. (I 649) Syntagma philosophiae Epicuri cum refutationibus dogmatum quae contra fidem christianam ab eo assertum sunt. Lyon: Guillaume Barbier.

Gilson, Étienne. ([I9I3] I960) Index scolastico-cartésien. Paris: Vrin.

Gournay, Marie Le Jars de. (2002) Apology for the Woman Writing and Other Works. Translated and edited by R. Hillman and C. Quesnel. Chicago: University of Chicago Press.

Gournay, Marie Le Jars de. (2002) Oeuvres Complètes. Edited by J.-C. Arnould. Paris: HonoréChampion.

Hagengruber, Ruth. (2015) 'Cutting through the Veil of Ignorance: Rewriting the History of Philosophy'. The Monist, 98, 34-42.

Hume, David. ([I779] 2007) Dialogues Concerning Natural Religion. New York: Cambridge University Press.

Janiak, Andrew. (2007) Newton as Philosopher. New York: Cambridge University Press.

Kuklick, Bruce. ( 1984 ) 'Seven Thinkers and How They Grew: Descartes, Spinoza Leibniz. Locke, Berkeley, Hume, Kant'. In R. Rorty, J. B. Schneewind, and Q. Skinner (eds.), Philosophy in History (New York: Cambridge University Press), I25-39.

Lehrer, Keith. (1989) Thomas Reid. New York: Routledge.

Locke, John. ([I690] I975) An Essay Concerning Human Understanding. Edited by P. H. Nidditch. Oxford: Clarendon Press.

Locke, John. ([ז693] 2000) Some Thoughts Concerning Education. Edited by John Yolton and Jean Yolton. Oxford: Clarendon Press.

Lolordo, Antonia. (2007) Pierre Gassendi and the Birth of Early Modern Philosophy. New York: Cambridge University Press.

Lucretius. ([56] 1975) De rerum natura. Edited by M. F. Smith and translated by W. H. D. Rouse. London and Cambridge, MA: Loeb Classical Library.

Malebranche, Nicolas. ([r688] 1997) Dialogues on Metaphysics and Religion. Translated and edited by Nicholas Jolley and David Scott. Cambridge, UK: Cambridge University Press.

Malebranche, Nicolas. ([1674] 1997) The Search After Truth. Translated and edited by Thomas Lennon and Paul Olscamp. Cambridge: Cambridge University Press.

Mandeville, Bernard de. (I7I4) The Fable of the Bees, or Private Vices, Publick Benefits. London: J. Roberts.

Montaigne, Michel de. (1958) The Complete Essays. Translated by Donald Frame. Stanford, CA: Stanford University Press.

Nadler, Steven. (1992) Malebranche and Ideas. New York: Oxford University Press.

Peterman, Alison. (2015) 'Spinoza on Extension'. Philosopher's Imprint, I 5, I4.

Popkin, Richard. ([1979] 2004) The History of Scepticism: From Erasmus to Spinoza. Berkeley, CA: University of California Press. Revised as The History of Scepticism: From Savonarola to Bayle. New York: Oxford University Press.

Poullain de la Barre, François. (2002) Three Cartesian Feminist Treatises. Edited by M. M. Welch and translated by V. Bosley. Chicago: University of Chicago Press.

Poullain de la Barre, François. ([ I673] 20I I) De l'égalité des deux sexes, De l'éducation des dames, De l'excellence des hommes. Edited by Marie-Frédérique Pellegrin. Paris: Vrin.

Rorty, Richard. (1984) 'The Historiography of Philosophy: Four Genres'. In R. Rorty, J. Schneewind, and Q. Skinner (eds.), Philosophy and Its History (New York: Cambridge University Press), 49-76.

Schmaltz, Tad. (1996) Malebranche's Theory of the Soul: A Cartesian Interpretation. New York: Oxford University Press.

Schmaltz, Tad. (2002) Radical Cartesianism: The French Reception of Descartes. Cambridge, UK: Cambridge University Press.

Schneewind, J.B. (I998) The Invention of Autonomy. Cambridge: Cambridge University Press.

Shapiro, Lisa. (2008) “"Turn My Will in Completely the Opposite Direction”: Radical Doubt and Descartes's Account of Free Will'. In Paul Hoffman, David Owen, and Gideon Yaffe (eds.), 
Contemporary Perspectives on Early Modern Philosophy: Essays in Honor of Vere Chappell (Peterborough, ON: Broadview Press), 2 I-39.

Shapiro, Lisa. (2004) 'Some Thoughts on the Place of Women in Early Modern Philosophy'. In Lilli Alanen and Charlotte Witt (eds.), Feminist Reflections on the History of Philosophy (Dordrecht, Boston: Kluwer Academic Publishers), 2 I9-50.

Shapiro, Lisa. (1999) 'Cartesian Generosity'. In 'Norms and Modes of Thinking in Descartes'. Acta Philosophica Fennica, 64, 249-75.

Spinoza, Baruch. (1677/1994). A Spinoza Reader: The Ethics and Other Works. Translated and edited by E. Curley. Princeton, NJ: Princeton University Press.

Van Cleve, James. (2002) 'Thomas Reid's Geometry of Visibles'. Philosophical Review, i I , 3, 373-4I6.

Van Cleve, James. (2007) 'Reid's Answer to Molyneux's Question'. The Monist, 90, 2, 25 I-70.

van Schurman, Anna Maria. (1998) Whether a Christian Woman Should Be Educated and Other Writings from her Intellectual Circle. Translated and edited by Joyce L Irwin. Chicago: University of Chicago Press.

Waithe, Mary Ellen. (2015) 'From Canon Fodder to Canon-Formation: How Do We Get There From Here?' The Monist, 98, 2I-33.

Watson, Richard. (1987) The Breakdown of Cartesian Metaphysics. Atlantic Highlands, NJ: Humanities Press. 